\title{
Ann Palmer: Realizing the College Dream with Autism or Asperger Syndrome
}

\author{
Jessica Kingsley Publishers, London and Philadelphia, PA., 2006, 176 pp., \$19.95
}

\author{
Jane Thierfeld Brown
}

Published online: 12 August 2009

(C) Springer Science+Business Media, LLC 2009

I had to start Ann Palmer's book, "Realizing the College Dream with Autism or Asperger Syndrome," three times. Palmer's first person account of her son's diagnosis was so heartfelt and well written that it sent me back to my own son's diagnosis 14 years ago. It was too hard a place to go back to and thus I kept putting the book down. On the third try I pushed myself through the emotion and was glad I did.

"Realizing the College Dream...." follows Ann Palmer's son Eric from his initial diagnosis, briefly through the school years, then concentrates on the college years. The central points she discusses concern choosing a college, transitioning and adjusting to a new way of living. Palmer does this with a personal and informed view of the special needs parent who has learned what her child needs. This book is also about a parent and what she went through having to let go of a son she worried about constantly, yet had the faith that he could succeed at college based on years of preparation.

Ann Palmer is quite obviously an exceptional parent with an outstanding school system. The educational program worked well for her son Eric and when it did not, Ann was there to assist. She became well educated and knowledgeable about the higher education process for her son's move to college and thus had Eric well-prepared too.

As a parent of an autistic 17 year old and having spent 30 years in Disability Services in Colleges and Universities, to me, Palmer's observations are useful and interesting, but the reader must remember this is one parent's experience about her son navigating through college. Palmer gives some excellent advice, such as having your high school son or daughter work after school and in the summer to gain

J. T. Brown ( $\square)$

University of Connecticut School of Law, College Autism

Spectrum, LLC, Hartford, CT, USA

e-mail: jane.brown@law.uconn.edu experience and independence (p. 58,) and questions to discuss with Disability Services (p. 63). Eric Palmer attends a college of 30,000 plus students (p. 60) and lives on campus, which would be impossible for many students with autism or Asperger's. However, his success and the author's careful planning hold useful information for many parents.

At times in the book Palmer assumes knowledge parents may not have, "Parents can be a good resource for the student in deciding what courses to take, how to balance difficult and easier courses, and the amount of hours the student should take" (p. 112). This is actually much better left to a college advisor who knows the workload of courses and professors. The overall advising aspect of higher education can be a difficult place to involve parents.

In all, Realizing the College Dream... is a useful and instructional book for parents to glean ideas for their child about education beyond high school and to help them start thinking about college as a possibility. Parents who read this book should also research the college point of view, such as in:

Students with Asperger Syndrome: A Guide for College Personnel by Lorraine E. Wolf, Ph.D., Jane Thierfeld Brown, Ed.D., and Ruth Bork, Ms.Ed., (AAPC 2009) and College Students with Asperger Syndrome: Practical Strategies to Ensure Social and AcademicSuccess by Rodney E. Pennamon, Director, and Louise Bedrossian, Assistant Director (LRP 2007).

Parents will also find the student point of view very useful, such as in:

Aquamarine Blue 5: Personal Stories of College Students with Autism (Paperback) by Dawn Prince-Hughes.

For the parent's point of view, Ann Palmer has contributed to the literature with a valuable piece. Parents who are unsure of their son or daughter's future can expand their thinking about options by reading this book. 